\title{
Effect of Work Atmosphere, Training, Incentives, and Motivation on Sales Productivity in PT. Suzuki Indonesia
}

\author{
Sigit Setiawan \\ University State of Jakarta \\ Email: sigitsetiawan_im12s3@mahasiswa.unj.ac.id \\ Bedjo Sujanto \\ University State of Jakarta \\ Email: bejosujanto@unj.ac.id \\ Dedi Purwana \\ University State of Jakarta \\ Email: dpurwana@unj.ac.id
}

\begin{abstract}
The aims of this study effect of work atmosphere, training, incentives, and motivation on sales force productivity at PT. Suzuki Indonesia. This study uses correlational studies. The sample from this study was 120 people selling PT. Suzuki Indonesia personnel in the Jabodetabek area. The results of this study indicate that; 1) The work environment has a positive direct effect on the productivity of the sales force of 0.613 with a tcount of $8.43,2$ ) training has a positive direct effect on sales force productivity of 0.628 with a tcount of $8.77,3$ ) incentives have a positive direct effect on labor productivity sales of 0.609 with a tcount of $8.34,4$ ) motivation has a positive direct effect on sales force productivity of 0.635 with a tcount of $8.94,5)$ work environment, training, incentives, and motivation together have a positive direct effect on productivity sales force of 0.812 with a tcount of 55.78. Thus an increase in sales force productivity can be achieved well if there is a strong influence of the work environment, training, incentives and motivation that are well-developed.
\end{abstract}

Keywords: work atmosphere, training, incentives, motivation and sales force productivity

Received: 21 September 2019 ;

Accepted: 11 October 2019 ;

Publish; December 2019.

\section{How to Cite:}

Setiawan, S., Sujanto, B., M.R, \& Purwana, D. (2019). Effect of Work Atmosphere, Training, Incentives, and Motivation on Sales Productivity in PT. Suzuki Indonesia. International Journal of Human Capital Management, 3 (2), 61-69. https://doi.org/10.21009/IJHCM.03.02.06 


\section{INTRODUCTION}

Nowadays business competition is so fierce that a profit-oriented company cannot just do business only mediocre, to be able to survive and grow must do extraordinary things that are not done by other companies or at least have to do more than the company competing companies. One important factor that can make a company survive and grow is to improve the quality of its sales force so that it can become a healthy company.

PT. Suzuki Indomobil is one of the top ATPM (Sole Agent Brand Holders) in our country with products of cars and motorbikes that are very well known in the community such as Vitara, Carry, Ertiga, Apv and so on, while the production of the very famous motorcycle Satria FU, Shogun, Thunder and others, with sales of hundreds of thousands for cars. In 2013 PT. Suzuki Indomobil was able to record 164,004 units of four-wheeled sales and in 2014 there were 154,923 units and in 2015 there were 121,805 units. In 2015, there was a significant decrease of 33,118 units due to declining purchasing power (Gaikindo, 2015). According to the chairman of Gaikindo Sudirman M Rusdi nationally during 2015 decreased 13.7 percent compared to before.

Technically productivity is described as the ratio of output to output. As explained by John W. Newstroom (2008: 13-14) who argues that, "Productivity is a ratio that compares units of output with units of input, often against a predetermined standard. If more outputs can be produced from the same amount of inputs, productivity is improved". That productivity is basically a ratio between input (input) and output (output). The above confirms that productivity always relies on two main components, namely input (input) and output (output). If both components have proportional quantities, then it can be said to be productive. This opinion explains that in an organization it is always endeavored to suppress inputs and optimize outputs.

Robbins and Judge (2013:28) which states that "an organization is productive if it achieves its goals by transforming inputs into output at the lowest cost. Thus productivity requires both effectiveness and efficiency". An organization can be said to be productive if the organization is able to achieve its objectives, changing inputs into outputs at the lowest cost. Therefore productivity reflects attention to effectiveness and efficiency.

Ivancevich and Konopaske (2013:36) define productivity is "productivity is defined as output of goods and services per unit of input of resources used in the production process". Productivity is defined as the output of goods and services per unit of input of resources used in the production process.

A salesperson must have in-depth salesmanship knowledge to be able to successfully close the sale. Such as sales interviews, attitude, personality, and good marketing management knowledge. The attitude of courtesy is also very necessary by the sales force, because with a friendly and polite attitude will cause a sense of pleasure and trust of a customer to the sales force. Because selling is transferring our beliefs to other people.

\section{LITERATURE REVIEW}

According to Murali Chemutur, and Thomas M. Cagley (2010:271) productivity is "productivity can also be defined and expressed as the amount of output per unit input. The term productivity is normally used in the context of human beings who are performing work". Productivity can also be defined and expressed as the amount of output per unit of input. The term productivity is usually used in the context of people who do work. A person's productivity depends on activities and working conditions.

The work atmosphere (Work Environment) is one of the factors that can increase the productivity of the sales force. Because with a comfortable working environment there will be positive energy and enthusiasm from the sales force to work optimally. With the availability of a decent room and comfortable air temperature and good communication facilities and harmonious relations with colleagues and superiors will certainly greatly affect the sales force in making appointments with customers, conducting meetings, also making offers and finally negotiating with customers to get order. According to Robbins and Timothy (2012:540): An organization's environment includes outside institutions or forces that can 
affect its performance, such as suppliers, customers, competitors, government regulatory agencies and public pressure groups. An organizational environment includes outside institutions or forces that can affect company performance, such as suppliers, customers, competitors, government agencies, regulations and public pressure groups.

Jennifer M. George and Gareth R. Jones (2012:546): The organizational environment is the set of forces surrounding an organization that determines its ability to obtain resources. These resources include inputs such as raw materials and skilled employees that an organization needs to produce goods and services. An organizational environment is a set of strengths in an organization that determines the ability to get resources. These resources include inputs such as raw materials and skilled employees, that an organization needs to produce goods and services. The definition implies that the work environment such as an organization has a central role in determining the input to support the expected goals in an organization.

Training is needed to improve the skills and knowledge of the sales force to be able to attract the sympathy and empathy of the customer towards him. One effort that needs to be done is to organize a leadership, continuous, and planned education and training program (leadership training) so that it is expected to produce leaders who have managerial competence, insight and broad vision and professionals in their fields.

Delors is quoted in Lagat (20017:87) argued that: Education has four pillars: learning to know, learning to do, learning to be and learning to live together. Learning to be and learning to live are pillars that are more directly related to the psychological development of the child hence more specific skills than general, technical or vocational are needed to prepare adolescents to 'learn to be' and to learn to 'live together.

Alwi was quoted in Afrizal (2017:62) stated that an education program is said to be successful if students are able to follow education well and can apply new competencies so that there is an increase in performance, both individually and organizationally. Furthermore, Rue was quoted in Afrizal emphasizing the measurement of the results of educational programs on individual practices including their work and assignments.

Colquitt, LePine and Wesson (2013:593) define "Training is a systematic effort by organizations to facilitate the learn of job-related knowledge and behavior". Training is a systematic organizational effort to facilitate learning related to knowledge and behavior.

The personality of a seller must be good, by maintaining a neat and clean appearance, starting from a polite haircut, polite clothes, neat and clean, clean shoes, fragrant body odor is a success factor of a seller. A good personality will cause sympathetic feelings and prospective customers arise in him.

Good marketing management knowledge will also be the key to a salesperson's success. By knowing marketing management a salesperson will be effective and efficient. By understanding the basic marketing management at least the salesperson will not waste much time aiming at the target consumer, what level of financial ability to buy the product.

4P marketing mix (Product, Price, Promotion, Placement) + 2P (People, Presentation) + Service is knowledge that salespeople must-have. By understanding the marketing mix, the salesperson will have a strategy in selling and will provide the best service to customers (Kottler, 2012:522).

Incentives are factors that provide salespeople with enthusiasm and encouragement to work better to achieve the specified targets so that they get more income to help increase production. Incentives as a motivational tool that encourages salespeople to work optimally, which is intended as extra income outside the salary or wage that has been set. The provision of incentives is intended to meet the needs of employees and their families. These incentives are generally used to describe wage payment plans that are directly or indirectly related to various employee performance or organizational profitability. Incentives can motivate as rewards to accommodate employees whose performance exceeds established standards. Incentives are a motivation for employees to work better so that employee performance can improve.

Motivation is one of the factors that can increase sales force productivity because with high motivation a salesperson will work optimally to achieve sales targets. Rue and Byars (2010:62), "motivation means getting people to exert a high degree of effort in their job. A 
motivated employee is an employee who tries hard." Motivation means getting people to put the highest effort into their work. Motivated employees are employees who try hard. Ivancevich and Kanopaske (2012:54) stated, "motivation is the set of attitudes that predisposes a person to act in a specific goal-directed way." Motivation is a set of attitudes that predispose a person to act in a way that is directed towards a particular goal.

\section{METHODOLOGY}

This study uses a quantitative approach with a survey method, namely research aimed at assessing large and small populations by selecting \& reviewing selected samples from the population to find the relative incidence, distribution, and interrelation of sociological and psychological variables. In addition, according to Chairman, this type of research also aims to find out and find the momentary position variable (status quo variable) based on existing data at the time (status quo data) and the relationship between the variables studied can then be determined and conclusions drawn. This research was conducted in the marketing office of PT. Suzuki Indomobil Sales in the Jabodetabek marketing area for 6 months, starting from May 2016 to September 2016. The affordable population in this study is PT. Suzuki Indonesia's sales force in the Greater Jakarta area, which the authors will take as many as 172 salespeople. The influence between these variables can be described in the form of a constellation as follows:

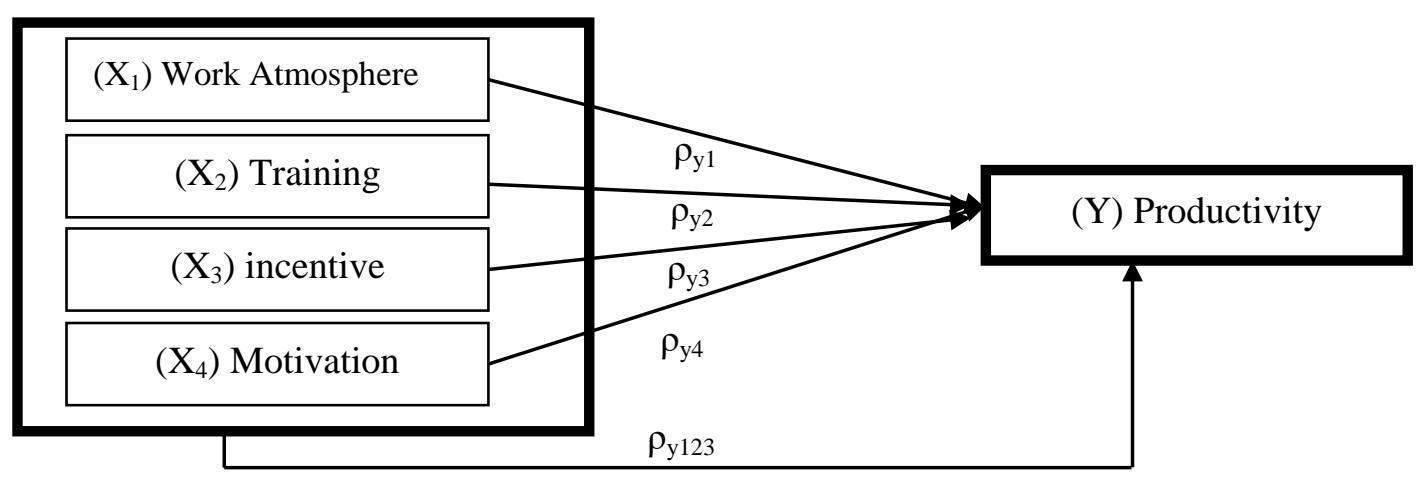

Figure 1 Hypothetical Research Model

\section{RESULT AND DISCUSSION}

\section{A. Data Description}

After going through the data collection process, data analysis is then performed which are discussed in succession in Chapter IV, including: (1) data description for each variable; (2) testing the analysis requirements, in the form of a normality test; (3) hypothesis testing the relationship between independent and dependent variables, both individual (simple) relationships, and joint (multiple) relationships. The recapitulation of the results of the descriptive statistical calculations above can be seen in the following table.

Table 1. Summary of Descriptive Statistics

\begin{tabular}{lccccc}
\hline \multicolumn{1}{c}{ Information } & $\mathbf{Y}$ & $\mathbf{X}_{\mathbf{1}}$ & $\mathbf{X}_{\mathbf{2}}$ & $\mathbf{X}_{\mathbf{3}}$ & $\mathbf{X}_{\mathbf{4}}$ \\
\hline Mean & 124,67 & 131,72 & 156,08 & 124,05 & 125,46 \\
\hline Standard Error & 0,54 & 0,56 & 0,57 & 0,64 & 0,53 \\
\hline Median & 125,0 & 132,0 & 156,0 & 123,0 & 126,0 \\
\hline Modus & 122 & 130 & 156 & 127 & 126 \\
\hline Standard Deviation & 5,93 & 6,14 & 6,20 & 7,06 & 5,76 \\
\hline Variations & 35,1989 & 37,6501 & 38,4061 & 49,8798 & 33,1411 \\
\hline Range & 28 & 30 & 29 & 28 & 29 \\
\hline Lowest & 107 & 116 & 139 & 109 & 108 \\
\hline The highest & 135 & 146 & 168 & 137 & 137 \\
\hline Total score & 14960 & 15806 & 18729 & 14886 & 15055 \\
\hline
\end{tabular}

B. Testing Requirements Analysis 
There are three conditions that must be met before conducting a regression analysis, both simple regression and multiple regression, namely (1) normality error estimation test; (2) homogeneity variance test, and (3) significance test and regression linearity test. Of the three requirements, there is only one requirement that is described in this section, the normality test, while the significance test and linearity regression test are tested in testing the research hypothesis. Recapitulation of test results for normality testing of estimated error of regression as shown in the following table.

Table 2. Test Results for Regression Estimation Normality

\begin{tabular}{ccccc}
\hline $\begin{array}{c}\text { Regression } \\
\text { Estimated Error }\end{array}$ & $\mathrm{N}$ & $\mathrm{L}_{\text {count it }}$ & $\begin{array}{c}\mathrm{L}_{\text {tabel }} \\
\alpha=0,05\end{array}$ & Information \\
\hline $\mathrm{Y}-\mathrm{X}_{1}$ & 120 & 0,0540 & 0,081 & Normal distribution \\
\hline $\mathrm{Y}-\mathrm{X}_{2}$ & 120 & 0,0571 & 0,081 & Normal distribution \\
\hline $\mathrm{Y}-\mathrm{X}_{3}$ & 120 & 0,0339 & 0,081 & Normal distribution \\
\hline $\mathrm{Y}-\mathrm{X}_{4}$ & 120 & 0,0585 & 0,081 & Normal distribution \\
\hline
\end{tabular}

\section{Research Hypothesis Testing}

1. Hypothesis One

Based on the calculation results obtained by the product-moment correlation coefficient between the work environment on productivity r1y of 0.613 . The test results obtained tcount (8.43) is greater than t table (1.98) at $\alpha=0.05$. The results of the coefficient significance test are in the hypothesis testing appendix.

\section{Table 3. Significant Test Results of Simple Correlation Coefficient between X1 and Y}

\begin{tabular}{|c|c|c|c|}
\hline Dk & Simple Correlation Coefficient & $\mathbf{T}_{\text {count }}$ & $\begin{array}{c}\mathbf{t}_{\text {tabel }} \\
\alpha=0,05\end{array}$ \\
\hline 118 & $r_{1 y}=0,613$ & $8,43 * *$ & 1,98 \\
\hline
\end{tabular}

Berdasarkan hasil di atas, maka dapat disimpulkan bahwa $\mathrm{H}_{0}$ ditolak dan menerima $\mathrm{H}_{1}$. Dengan kata lain terdapat pengaruh positif yang sangat signifikan antara lingkungan kerja terhadap produktivitas. Dari koefisien korelasi tersebut dapat dihitung pula koefisien determinasinya $\left(\mathrm{r}_{1 \mathrm{y}}\right)^{2}=(0,613)^{2}=0,3761$; yang berarti bahwa $37,61 \%$ proporsi varians produktivitas dapat dijelaskan oleh lingkungan kerja.

Pengaruh antara lingkungan kerja terhadap produktivitas, bila variabel lain dikontrol, dilakukan dengan analisis korelasi parsial. Koefisien korelasi parsial yang diperoleh dan hasil pengujiannya disajikan pada tabel berikut.

\section{Tabel 3. Hasil Uji Signifikan Koefisien Korelasi Parsial antara $X_{1}$ dengan $Y$}

\begin{tabular}{cccc}
\hline Dk & Koefisien Korelasi Parsial & $\mathbf{t}_{\text {hitung }}$ & $\begin{array}{c}\mathbf{t}_{\text {table }} \\
\boldsymbol{\alpha}=\mathbf{0 , 0 5}\end{array}$ \\
\hline 117 & $\mathrm{r}_{\mathrm{y} 1.2}=0,462$ & $5,64 * *$ & 1,98 \\
\hline 117 & $\mathrm{r}_{\mathrm{y} 1.3}=0,498$ & $6,21 * *$ & 1,98 \\
\hline 117 & $\mathrm{r}_{\mathrm{y} 1.4}=0,432$ & $5,18 * *$ & 1,98 \\
\hline$* *$ very significant $\left(\mathrm{t}_{\mathrm{count}}=7,25>\mathrm{t}_{\text {table }}=1,98\right)$ & & \\
\end{tabular}

Regression equation $\hat{Y}=30.79+0.60 \mathrm{X} 2$, for the significance test obtained Fcount 76.96 is greater than Ftable $(0.05 ; 1: 118) 3.92$ at $\alpha=0.05$. Because Fcount $>$ Ftable, the regression equation is stated to be very significant. For the linearity test, the Fcount is 1.28 smaller than the Ftable $(0.05 ; 25$ : 93) of 1.62 at $\alpha=0.05$. Because Fcount $<$ Ftable, the estimated point distribution forming a linear line is acceptable.

\section{Second Hypothesis}

Based on the calculation results obtained by the product-moment correlation coefficient between training on productivity $\mathrm{r} 2 \mathrm{y}$ of 0.628 . The test results obtained $\mathrm{t}$ count 
(8.77) are greater than $t$ table (1.98) at $\alpha=0.05$. The results of the coefficient significance test are in the hypothesis testing appendix.

Table 4. Significant Test Results of Simple Correlation Coefficient between X2 and Y

\begin{tabular}{cccc}
\hline Dk & Simple Correlation Coefficient & $\mathbf{t}_{\text {count }}$ & $\begin{array}{c}\mathbf{t}_{\text {table }} \\
\boldsymbol{\alpha}=\mathbf{0 , 0 5}\end{array}$ \\
\hline 118 & $\mathrm{r}_{2 \mathrm{y}}=0,628$ & $8,77^{* *}$ & 1,98 \\
\hline
\end{tabular}

$* *$ very significant (tcount $=7.25>$ ttable $=1.98)$

Based on the above results, it can be concluded that $\mathrm{H} 0$ is rejected and accepts $\mathrm{H} 1$. In other words, there is a very significant positive effect between training on productivity. From the correlation coefficient can also be calculated the coefficient of determination (r2y) $2=$ (0.628) $2=0.3948$; which means that $39.48 \%$ of the proportion of productivity variance can be explained by training.

The effect of training on productivity, when other variables are controlled, is done by partial correlation analysis. The partial correlation coefficients obtained and the test results are presented in the following table.

Table 5. Significant Test Results of Partial Correlation Coefficients between X2 and Y

\begin{tabular}{cccc}
\hline dk & Partial Correlation Coefficient & $\mathbf{T}_{\text {count }}$ & $\begin{array}{c}\mathbf{t}_{\text {table }} \\
\boldsymbol{\alpha}=\mathbf{0 , 0 5}\end{array}$ \\
\hline 117 & $\mathrm{r}_{\mathrm{y} 2.1}=0,487$ & $6,03 * *$ & 1,98 \\
\hline 117 & $\mathrm{r}_{\mathrm{y} 2.3}=0,507$ & $6,37 * *$ & 1,98 \\
\hline 117 & $\mathrm{r}_{\mathrm{y} 2.4}=0,518$ & $6,55 * *$ & 1,98 \\
\hline$* *$ very significant $\left(\mathrm{t}_{\text {count }}=7,25>\mathrm{t}_{\text {table }}=1,98\right)$ & &
\end{tabular}

\section{Third Hypothesis}

Based on the calculation results obtained by the product-moment correlation coefficient between incentives to productivity $\mathrm{r} 3 \mathrm{y}$ of 0.609 . The test results obtained tcount (8.34) is greater than ttable (1.98) at $\alpha=0.05$. The results of the coefficient significance test are in the hypothesis testing appendix.

Table 6. Significant Test Results of Simple Correlation Coefficient between X3 and Y

\begin{tabular}{cccc}
\hline $\mathbf{d k} \quad$ Simple Correlation Coefficient & $\mathbf{t}_{\text {count }}$ & $\begin{array}{c}\mathbf{t}_{\text {table }} \\
\boldsymbol{\alpha}=\mathbf{0 , 0 5}\end{array}$ \\
\hline 118 & $\mathrm{r}_{3 \mathrm{y}}=0,609$ & $8,34 * *$ & 1,98 \\
\hline$* *$ very significant $\left(\mathrm{t}_{\text {count }}=8,34>\mathrm{t}_{\text {table }}=1,98\right)$ & &
\end{tabular}

Based on the above results, it can be concluded that $\mathrm{H} 0$ is rejected and accepts $\mathrm{H} 1$. In other words, there is a very significant positive effect between incentives on productivity. From the correlation coefficient can also be calculated the coefficient of determination (r3y) 2 $=(0.609) 2=0.3707$; which means that $37.07 \%$ of the proportion of productivity variance can be explained by incentives.

The effect of incentives on productivity, if other variables are controlled, is done by partial correlation analysis. The partial correlation coefficients obtained and the test results are presented in the following table.

Table 7. Significant Test Results of Partial Correlation Coefficients between X3 and Y

\begin{tabular}{cccc}
\hline $\mathbf{d k}$ & Partial Correlation Coefficient & $\mathbf{t}_{\text {count }}$ & $\begin{array}{c}\mathbf{t}_{\text {table }} \\
\boldsymbol{\alpha}=\mathbf{0 , 0 5}\end{array}$ \\
\hline 117 & $\mathrm{r}_{\mathrm{y} 3.1}=0,492$ & $6,11^{* *}$ & 1,98 \\
\hline 117 & $\mathrm{r}_{\mathrm{y} 3.2}=0,477$ & $5,88^{* *}$ & 1,98 \\
\hline 117 & $\mathrm{r}_{\mathrm{y} 3.4}=0,478$ & $5,89 * *$ & 1,98 \\
\hline$* *$ very significant $\left(\mathrm{t}_{\mathrm{count}}=7,25>\mathrm{t}_{\text {table }}=1,98\right)$ & &
\end{tabular}


Based on the results of the table, it can be concluded that the partial correlation coefficient between incentives to productivity, if the work environment is controlled is very meaningful (very significant), so it can be interpreted that, if the work environment is controlled still, then incentives contribute significantly to productivity. The partial correlation coefficient between incentives to productivity, if the training is controlled is very meaningful (very significant), so it can be interpreted that, if the training is controlled fixed, then the incentives contribute significantly to productivity. The partial correlation coefficient between incentives to productivity, if motivation is controlled is very meaningful (very significant), so it can be interpreted that, if motivation is controlled, then incentives contribute significantly to productivity.

\section{Fourth Hypothesis}

Based on the calculation results obtained by the product-moment correlation coefficient between motivation to productivity $\mathrm{r} 4 \mathrm{y}$ of 0.635 . The test results obtained tcount (8.94) is greater than ttable (1.98) at $\alpha=0.05$. The results of the coefficient significance test are in the hypothesis testing appendix.

\section{Table 8. Significant Test Results of Simple Correlation Coefficient between X4 and Y}

\begin{tabular}{cccc}
\hline dk & Simple Correlation Coefficient & $\mathbf{t}_{\text {count }}$ & $\begin{array}{c}\mathbf{t}_{\text {table }} \\
\boldsymbol{\alpha}=\mathbf{0 , 0 5}\end{array}$ \\
\hline 118 & $\mathrm{r}_{4 \mathrm{y}}=0,635$ & $8,94 * *$ & 1,98 \\
\hline$* *$ very significant $\left(\mathrm{t}_{\text {count }}=7,25>\mathrm{t}_{\text {table }}=1,98\right)$ & &
\end{tabular}

Based on the above results, it can be concluded that $\mathrm{H} 0$ is rejected and accepts $\mathrm{H} 1$. In other words, there is a very significant positive effect between motivation on productivity. From the correlation coefficient can also be calculated the coefficient of determination (r1y) 2 $=(0.635) 2=0.4037$; which means that $40.37 \%$ of the proportion of productivity variance can be explained by motivation.

The effect of motivation on productivity, when other variables are controlled, is done by partial correlation analysis. The partial correlation coefficients obtained and the test results are presented in the following table.

Table 4.1 Test Results Significant Partial Correlation Coefficient between X4 and $Y$

\begin{tabular}{cccc}
\hline dk & Partial Correlation Coefficient & $\mathbf{t}_{\text {hitung }}$ & $\begin{array}{c}\mathbf{t}_{\text {tabel }} \\
\boldsymbol{\alpha}=\mathbf{0 , 0 5}\end{array}$ \\
\hline 117 & $\mathrm{r}_{\mathrm{y} 4.1}=0,472$ & $5,78^{* *}$ & 1,98 \\
\hline 117 & $\mathrm{r}_{\mathrm{y} 4.2}=0,528$ & $6,73 * *$ & 1,98 \\
\hline 117 & $\mathrm{r}_{\mathrm{y} 4.3}=0,519$ & $6,56 * *$ & 1,98 \\
\hline$* *$ very significant $\left(\mathrm{t}_{\text {count }}=7,25>\mathrm{t}_{\mathrm{table}}=1,98\right)$ & &
\end{tabular}

\section{Fifth Hypothesis}

The research hypothesis tested was formulated as follows: "there is a positive influence between the work environment, training, incentives, and motivation together on productivity".

Table 4.1 ANAVA for the Four Predictors' Multiple Regression Equations $\hat{\mathbf{Y}}=$ $-11,18+0,21 X_{1}+0,28 X_{2}+0,22 X_{3}+0,30 X_{4}$

\begin{tabular}{lccccc}
\hline $\begin{array}{c}\text { Source } \\
\text { Variance }\end{array}$ & $\mathbf{d k}$ & $\begin{array}{c}\text { Number of } \\
\text { Squares }(\mathbf{J K})\end{array}$ & $\begin{array}{c}\text { Average Number } \\
\text { of Squares }(\mathbf{R J K})\end{array}$ & $\mathbf{F}_{\text {count }}$ & $\begin{array}{c}\mathbf{F}_{\text {table }} \\
\boldsymbol{\alpha = 0 , 0 5}\end{array}$ \\
\hline Total & 4 & 2764,04 & 691,01 & \multirow{2}{*}{$55,78 * *$} & 2,45 \\
\hline Residu & 115 & 1424,63 & 12,39 & & \\
\hline$* *$ Multiple regression is very significant $\left(\mathrm{F}_{\text {count }}>\mathrm{F}_{\text {table }}\right)$ & &
\end{tabular}


The multiple correlation coefficient of the four independent variables with productivity $($ Ry.1234) $=0.812$. Significance test results obtained Fcount (55.78)> Ftable (2.45) at $\alpha=0.05$. Based on these results there is a positive influence between the work environment, training, incentives, and motivation together on productivity.

The coefficient of determination (Ry.1234) 2 of (0.812) $2=0.6599$ can be interpreted that $65.99 \%$ of the proportion of productivity variance can be explained jointly by the work environment, training, incentives, and motivation. Based on the results of further calculations it can be seen the contribution (contribution) of the dependent variable over the work environment by $37.61 \%$; training by $39.48 \%$; incentive of $37.07 \%$; and motivation by $40.37 \%$.

\section{DISCUSSION OF RESEARCH RESULTS}

\section{Effect of Work Environment on Productivity}

The results of testing the first hypothesis can be concluded that there is a positive influence between the work environment on productivity, where the correlation coefficient of 0.613 produces tcount $=8.43$ greater than $t$ table $=1.98$ at $\alpha=0.05$. The conclusion shows that the higher the work environment score, the higher the productivity. This is in accordance with the opinion According Sedarmayanti (2011: 175) work environment is the overall tools and materials faced, the surrounding environment in which a person works, and work arrangements both as individuals and as a group.

\section{Effect of Training on Productivty}

The results of the second hypothesis test can be concluded that there is a positive influence between training on productivity, where the correlation coefficient of 0.628 produces tcount $=8.77$ greater than $\mathrm{t}$ table $=1.98$ at $\alpha=0.05$. The conclusion shows that the higher the training score, the higher the productivity. This is consistent with the opinion of Colquitt, Lepine and Wesson (2009) explain The effect of learning on performance and commitment. Learning has a moderately positive effect on performance, employees, who gains more knowledge and skills tend to have higher levels of task performance and commitment. The effect of learning on performance and commitment. Learning has a moderate positive effect on performance, employees, who acquire more knowledge and skills tend to have a higher level of performance and commitment.

\section{Effect of Incentive on Productivity}

The results of testing the third hypothesis can be concluded that there is a positive influence between incentives on productivity, where the correlation coefficient of 0.609 produces tcount $=8.34$ greater than $\mathrm{t}$ table $=1.98$ at $\alpha=0.05$. These conclusions indicate that the higher the incentive score, the higher the productivity. From these results, it can also be interpreted that increasing incentive scores will make a meaningful contribution to productivity. Incentives are anything that encourages or has a tendency to stimulate activity, incentives are motives and rewards that are formed to improve production.

\section{Effect of Motivation on Productivity}

The fourth hypothesis testing results can be concluded that there is a positive influence between motivation on productivity, where the correlation coefficient of 0.635 produces tcount $=8.94$ greater than $\mathrm{t}$ table $=1.98$ at $\alpha=0.05$. The conclusion shows that the higher the motivation score, the higher the productivity. This is in accordance with the opinion According to Steven $\mathrm{P}$ Robin motivation as a process that also determines the intensity, direction, and perseverance of individuals in an effort to achieve goals.

\section{Effect of Work Environment, Training, Incentives, and Motivation Together on Productivity}

The results of testing the fifth hypothesis can be concluded that the work environment, training, incentives, and motivation together have a positive effect on productivity. The multiple correlation coefficient between the four independent variables to the dependent variable Ry.1234 of 0.812 produces Fcount $=55.78$ greater than Ftable $=2.45$ at $\alpha=0.05$. From the correlation coefficient, the coefficient of determination (Ry.1234) 2 can be calculated at 0.6599 meaning that $65.99 \%$ of the proportion of productivity variance can be explained jointly by the work environment, training, incentives, and motivation. From the 
description above both the work atmosphere, Training, Incentives, and Motivation each have a positive effect on Productivity, then automatically the working atmosphere, training, incentives, and motivation are thought to have a positive influence jointly on productivity

\section{CONCLUSION}

Based on the results of research and discussion as presented in Chapter IV, the findings and conclusions of this study are as follows: 1) The work environment has a direct positive effect on the productivity of the sales force. This means that a more conducive work environment in the work environment results in an increase in the productivity of the sales force. 2) Training has a direct positive effect on sales force productivity. This means that better training results in an increase in labor productivity. 3) Incentives have a direct positive effect on sales force productivity. This means that the higher intensive work environment results in an increase in labor productivity. 4) Motivation has a direct positive effect on sales force productivity. This means that higher work motivation leads to an increase in labor productivity. 5) The work environment, training, incentives, and motivation together have a direct positive effect on the productivity of the sales force. This means that a more conducive work environment, good training, good incentives and high motivation lead to increased sales force productivity.

\section{REFERENCES}

Byars Lloyd L. dan Leslie W. Rue, Human Resource Management: Present and Future Seventh Edition. The McGraw-Hill Companies, 2014.

Chemuturi, Murali dan Thomas M. Cagley, Mastering Software Project Management: Best Practices, Tools and Techniques. USA: Copyright J. Ross Publishing, 2010.

Colquitt, Jason A. J. Le Pine, dan Michael J.Weson, "Organization Behaviour, Improving Performance and Commitment in Work Place, New York: Mc.Graw-Hill/Irwin, 2015.

Gaikindo 2015

George, Jennifer M. and Gareth R. Jones, Organizational Behavior" third edition. New Jersey: Prentice-Hall, 2012.

Ivancevich, John M. dan Robert Konopaske, Human Resources Management. New York: McGraw Hill, 2013.

Kottler, Phillip and Keller, Lane, Kevin, Marketing Management, 14ed. Upper Saddle River, New Jersey Pearson Education, Inc, publishing as Prentice Hall, One Lake Street), 07458. 2012,

Lagat, Grace. Life Skills Education Curriculum Implementation: Appropriateness of Teaching Methodologies Used by Secondary School Teachers In Uasin Gishu County, Kenya. International Journal of Education, Learning and Development Vol.5, No.4, pp.86-95, June 2017.

Newstrom, John W. Organizational: Human Behavior at Wok Twelfth Edition. New York: McGraw-Hill/Irwin, 2008.

Robbins Stephen P. dan Timothy A Judge, Management Eleventh Edition. New Jersey: Pearson Prentice Hall, 2012.

Robbins Stephen P. dan Timothy A Judge, Organizational Behavior Fiteenth Edition. New Jersey: Pearson Education Inc. Publishing as Prentice Hall, 2013.

Y. Afrizal, The Evaluation of Education Program Implementation on Head of the Indonesian Republic Bank Unit. International Journal of Human Capital Management E-ISSN 2580-9164 Vol. 1, No.2, December 2017, 